\title{
Sediaan Farmasi yang Mengandung Mineral Untuk Veterinary Sapi
}

\author{
Ega Megawati, Nasrul Wathoni \\ Program Studi Sarjana Farmasi, Fakultas Farmasi, Universitas Padjadjaran, Sumedang, 45363 \\ email: ega16002@mail.unpad.ac.id
}

\begin{abstract}
Abstrak :
Mineral merupakan salah satu faktor yang dapat mempengaruhi kualitas dari hewan ternak dimana 3-5\% dari tubuh hewan ternak pada umumnya terdiri dari zat-zat mineral. Beberapa penyakit pada hewan ternak telah diketahui dipicu oleh adanya defisiensi mineral. Dalam Artikel ini akan dibahas apa saja gangguan atau penyakit yang mungkin terjadi akibat defesiensi penyakit pada hewan ternak Sapi dan bagaimana fungsi mineral itu sendiri, serta tinjauan mengenai sediaan-sediaan Farmasi. Hasil yang didapatkan adalah mineral akan mempengaruhi fungsiologi dari tubuh sapi sehingga mengakibatkan beberapa gangguan dan ditinjau dari 5 sediaan Farmasi yang telah ditemukan secara efektif dapat meningkatkan status mineral dengan bentuk sediaan oral maupun injeksi.
\end{abstract}

Kata kunci: Sapi, Mineral, Defisensi

\section{Outline}

- Pendahuluan

- Metode review

- Hasil

- Pembahasan

- Kesimpulan

\section{Pendahuluan}

Mineral adalah salah satu faktor yang mempunyai pengaruh besar pada kualitas dari hewan ternak, dimana kandungan zat-zat mineral dalam tubuh ternak berada dikisaran $3-5 \%$ dari masa tubuhnya (Arifin, 2007). Mineral yang ada pada tubuh hewan ternak dibagi menjadi 2 kelompok diantaranya adalah mineral Essensial serta mineral Nonesensial.

Pada Mineral Esensial biasanya berupa mineral yang dapat mempengaruhi fungsional tubuh hewan, sehingga apabila terjadi kekurangan Mineral Essensial pada hewan akan berakibat pada terganggunya pula fungsional tubuh hewan tersebut, contoh mineral essensial diantaranya (Herdt dan Hoff, 2011). Selanjutnya adapula Mineral Nonessensial yaitu mineral yang biasanya belum diketahui apa kegunaan dari mineral tersebut, apabila kandungan mineral nonessensial dalam tubuh berlebih maka hal tersebut dapat membahayakan bagi hewan (Kurnia, dkk, 2012). 
Mineral sendiri memiliki beberapa peran penting diantaranya pada proses terjadinya enzimatis maupun pada sistem hormonal, membantu regenerasi sel, berfungsi sebagai katalisator dan regulator, berpengaruh pada pertumbuhan sistem reproduksi dan imun tubuh hewan ternak (Soetan, et. al., 2010; Arifin, 2008).

Mineral merupakan salah satu senyawa yang tidak disintesis secara alami pada tubuh hewan sehingga untuk tetap dapat memenuhi kebutuhan mineral sehari- hari maka hewan ternak perlu diberikan tambahan mineral pada pakannya, namun pada umumnya para peternak lebih banyak memberikan pakan hijau saja tanpa mengerti akan pentingnya kebutuhan mineral sehingga akibatnya tidak sedikit para hewan ternak tersebut kemudian mengalami defisiensi mineral. (Arifin, 2008; Soetan et al., 2010)

Defisiensi Mineral sendiri merupakan suatu keadaan tubuh yang mengalami kekurangan mineral dimana kadar mineral dalam tubuh atau darah jauh lebih sedikit dibandingkan dengan kebutuhan mineral sehari-hari sehingga dapat menimbulkan kelainan fisiologi

(Liqyanan, dkk,2015). Kejadian Penyakit Defisiensi Mineral pada hewan ternak biasanya disebabkan karena mineral yang terkandung dalam pakan kurang dapat mencukupi kebutuhan sehari-hari tubuh hewan (Darmono, 2007), selain itu suhu, keadaan tanah serta tingkat kesuburannya, tipe dan jenis tanah, serta tanaman apa saja yang tumbuh di tanah tersebut juga menjadi salah satu faktor yang bisa mempengaruhi kandungan mineral pada tubuh hewan karena kandungan mineral yang terkandung pada setiap jenis tanah akan berbeda-beda (Cahyadi et al., 2016; Devi et al., 2014).

\section{Metode review}

Review artikel ini dikerjakan dengan menggunakan metode studi pustaka yang dimana dilakukan pengumpulan beberapa jurnal ataupun artikel melalui beberapa situs internet seperti Google Scholar atau Pubmed, serta situs-situs jurnal lainnya.

Tabel 1. Peran Mineral pada Veterinary Sapi

\begin{tabular}{|c|c|c|c|}
\hline Mineral & $\begin{array}{l}\text { Penyakit dan gangguan } \\
\text { pada Sapi }\end{array}$ & Peran Mineral & $\begin{array}{l}\text { Sumber } \\
\text { Pustaka }\end{array}$ \\
\hline $\mathrm{Zn}$ & $\begin{array}{l}\text { Berkurangnya nafsu makan, } \\
\text { mengalami } \\
\text { gangguan Dermatitis, terjadi } \\
\text { keterlambatan pertumbuhan } \\
\text { seksual serta kemandulan, } \\
\text { terjadi Abortus atau gangguan } \\
\text { pada pertumbuhan embrio, } \\
\text { Imunodefisiensi, terjadi } \\
\text { berbagai macam } \\
\text { infeksi, Parakeratosis. }\end{array}$ & $\begin{array}{l}\text { Membantu sintesis glukagon serta insulin, } \\
\text { berperan penting dalam metabolisme, } \\
\text { manjaga keseimbangan asam dan basa } \\
\text { tubuh, katalisator bagi enzim superoksida } \\
\text { dismutase, aminopeptidase, , collagenase, } \\
\text { alkalin fosfatase, dan karboksipeptidase. } \\
\text { dehidrogenase. }\end{array}$ & $\begin{array}{l}\text { (Widhyari, } \\
\text { 2012; } \\
\text { Elhashmi, et. } \\
\text { al., 2016) }\end{array}$ \\
\hline
\end{tabular}




\begin{tabular}{|c|c|c|c|}
\hline Mineral & $\begin{array}{l}\text { Penyakit dan gangguan } \\
\text { pada Sapi }\end{array}$ & Peran Mineral & $\begin{array}{l}\text { Sumber } \\
\text { Pustaka }\end{array}$ \\
\hline $\mathrm{Mg}$ & $\begin{array}{l}\text { Drowned Cow Syndrom, } \\
\text { Hypomagnesemic Tetany, Gangguan } \\
\text { pernafasan serta jantung, Anorexia, } \\
\text { mampu mengganggu pembentukkan } \\
\text { Parathormon dan zat aktif Vitamin } \\
\text { D. }\end{array}$ & $\begin{array}{l}\text { Berperan dalam membantu poses metabolisme protein, } \\
\text { lemak, dan karbohidrat. Berperan penting dalam proses } \\
\text { pembentukan ribosom, transport energi membran, } \\
\text { dengan mengikat fosfolipid maka Mg akan menjaga } \\
\text { kepadatan membran. Mengatur kontraksi otot dan } \\
\text { transmisi syaraf, serta sebagai salah satu komponen } \\
\text { utama penyusun tulang. }\end{array}$ & $\begin{array}{l}\text { (Dian, dkk, 2014; Lean et } \\
\text { al., 2006; Yanuartono, } \\
\text { et. al., 2016) }\end{array}$ \\
\hline $\mathrm{Cu}$ & $\begin{array}{l}\text { Enzootic Ataksia, Falling Disease, } \\
\text { penyakit Lechsucht, produksi dan } \\
\text { berat badan menurun, kemandulan, } \\
\text { serta kematian mendadak. }\end{array}$ & $\begin{array}{l}\text { Membantu memetabolisme Estrogen untuk meningkatkan } \\
\text { kesuburan }\end{array}$ & (Arifin, 2007) \\
\hline $\mathrm{Ca}$ & $\begin{array}{l}\text { Menurunnya produksi susu, Milk } \\
\text { Fever, Drowned Cow Syndrom, } \\
\text { mastitis subklinis, mastitis klinis, } \\
\text { retensi plasenta, metritis, terjadi } \\
\text { ovulasi postpartum dan } \\
\text { pneumonia. }\end{array}$ & $\begin{array}{l}\text { Pembentuk gigi dan tulang, menjaga kepadatan tulang, } \\
\text { mengatur hormon dan faktor pertumbuhan, mengatur: } \\
\text { sel saraf, terjadinya kontraksi pada otot, membantu } \\
\text { proses koagulasi serta mengatur permebialitas sel } \\
\text { membran. }\end{array}$ & $\begin{array}{l}\text { (Pujiastri, dkk, 2015; } \\
\text { Timothy et al. 2011) }\end{array}$ \\
\hline $\mathrm{Na}$ & $\begin{array}{l}\text { Sistem reproduksi terganggu, siklus } \\
\text { Estrus menjadi terganggu, terjadi } \\
\text { Endometritis dan memicu } \\
\text { pembentukan kista folikel nafsu } \\
\text { makan menurun, serta gangguan } \\
\text { absorbs Mastitis, Metritis, } \\
\text { Kemandulan, retens plasenta, } \\
\text { Malfungsi pada }\end{array}$ & $\begin{array}{l}\text { Mempertahankan suhu tubuh, mengatur transport kimiawi } \\
\text { serta kerja syaraf. }\end{array}$ & $\begin{array}{l}\text { (Pradhan and } \\
\text { Nakagoshi, }\end{array}$ \\
\hline $\mathrm{Se}$ & $\begin{array}{l}\text { hormon Testosteron dan sintesis } \\
\text { Spermatozoon, terganggunya produksi } \\
\text { susu, rambut }\end{array}$ & $\begin{array}{l}\text { Membantu pembentukan serta aktivitas dari sel T helper dan } \\
\text { NK, sebagai kompensasi saat terjadi akumulasi } \\
\text { hidroperoksida. }\end{array}$ & $\begin{array}{l}\quad \text { (Hefnawy, dan } \\
\text { Tórtora., 2010; Mehdi, } \\
\text { et.al., 2013) }\end{array}$ \\
\hline $\mathrm{P}$ & $\begin{array}{l}\text { Terjadi Anestrus, meningkatkan resiko } \\
\text { kematian embrio, terganggunya } \\
\text { perkembangan sistem reproduksi } \\
\text { sehingga terhambatnya proses Pubertas } \\
\text { dan Estrus Postpartus }\end{array}$ & $\begin{array}{l}\text { Mempertahankan struktur dan komposisi tulang, } \\
\text { mengatur. Permeabilitas sel, asam basa, serta aktivitas } \\
\text { enzim. sebagai salah satu penyusun myelin. }\end{array}$ & $\begin{array}{l}\text { (Orgen, 2013; } \\
\text { Yasothai, 2014) }\end{array}$ \\
\hline $\bar{K}$ & $\begin{array}{l}\text { Drowned Cow Syndrom, melemahnya } \\
\text { kekuatan otot tubuh dan otot uterus, } \\
\text { kemandulan, Metritis dan Retensi } \\
\text { Plasenta }\end{array}$ & $\begin{array}{l}\text { katalisator pada reaksi biologi dalam tubuh seperti pada } \\
\text { proses pembentukan glikogen maupun metabolisme ATP, } \\
\text { mengatur transmisi saraf serta relaksasi otot. }\end{array}$ & $\begin{array}{l}\text { Dwipartha, 2015; Lawton, } \\
\text { 2013; Sattler and Fecteau, } \\
\text { 2014) }\end{array}$ \\
\hline
\end{tabular}

Tabel. 2 Obat berbahan Mineral untuk sapi

\begin{tabular}{|c|c|c|c|}
\hline No & Formula & Bentuk Sediaan & Sumber Pustaka \\
\hline 1 & $\begin{array}{l}0.5 \quad \mathrm{mg} \text { sodium selenite } / \mathrm{ml} \\
50 \mathrm{mg} \text { tocopherol } \\
\text { acetate } / \mathrm{ml}\end{array}$ & Injeksi Intramuscular & (Żarczyńska, et. al., 2018) \\
\hline 2 & $\begin{array}{l}\text { Lidocaine } \\
\text { Dypirone } \\
\text { Oksitetrasiklin } \\
\text { Vitamin B1 } \\
\text { B-Kompleks } \\
\text { Multivitamin }\end{array}$ & Injeksi & (Nururrozi, dkk, 2016) \\
\hline 3 & $\begin{array}{l}\text { Mineral Zn } \\
\text { konsentrat } 60 \mathrm{ppm}\end{array}$ & Larutan & (Widhyari, dkk, 2015) \\
\hline 5 & $\begin{array}{l}60 \mathrm{mg} / \mathrm{mL} \mathrm{Zn} \\
10 \mathrm{mg} / \mathrm{mL} \mathrm{Mn} \\
15 \mathrm{mg} / \mathrm{mL} \mathrm{Mg} \\
5 \mathrm{mg} / \mathrm{mL} \mathrm{Cu}\end{array}$ & Injeksi Subkutan & Arthington, et. al.,2014) \\
\hline
\end{tabular}




\section{Pembahasan}

Mineral merupakan senyawa yang sangat penting dalam tubuh. Telah disebutkan dalam Tabel 1 yang secara garis besar dapat disebut bahwa mineral berperan dalam berbagai mekanisme dalam tubuh, sintesis protein dan hormon, serta mempengaruhi kualitas sistem reproduksi. Kejadian defisiensi mineral akan menyebabkan terganggunya fungsifungsi tersebut sehingga organ atau bagian tubuh terkait pun akan mengalami suatu gangguan dan apabila gangguan tersebut semakin banyak maka akan dapat dikategorikan sebagai suatu penyakit. Penyakit pada hewan ternak sapi yang diakibatkan oleh defisiensi mineral diantaranya Milk Fever, Drowned Cow Syndrom, Abortus atau kematian embrio sejak dini, Anorexia dan sebagainya.

Pengobatan untuk menangani defisiensi mineral pada hewan ternak sapi telah banyak dikembangkan baik dalam bentuk sediaan atau diet. Pada penelitian yang dilakukan oleh Żarczyńska, et. al. (2018) dilakukan pemberian obat injeksi intramuscular pada Sapi yang mengandung mineral Se yang dikombinasikan dengan tocopherol asetat dengan dosis $10 \mathrm{ml}$ dan $30 \mathrm{ml}$, didapatkan bahwa terjadi peningkatan kadar Se dalam serum sapi dibandingkan dengan kelompok kontrol yaitu 43.43 \pm 0.86 untuk kontrol, $47.77 \pm 0.92$ untuk Sapi yang diberikan obat dengan dosis $10 \mathrm{ml}$, dan $56.64 \pm 1.25$ untuk sapi yang diberikan obat dengan dosis $30 \mathrm{ml}$.

Selanjutnya adapula pada penelitian Nururrozi, dkk, (2016) yang dilakukan dengan membandingkan pengobatan pada sapi yang mengalami gejala sapi ambruk atau Drowned Cow Syndrom dimana sapi mengalami gejala Anorexia, tremor, pincang, hingga ambruk. Dilakukan pembandingan keefektifan pengobatan dengan kelompok 1 yaitu kombinasi antipiretik, antibiotik dan vitamin. Kelompok 2 dengan kombinasi antipiretik dan antibiotik, kelompok 3 dengan kombinasi antipiretik, antihistamin dan vitamin. Kelompok 4 dengan kombinasi antipiretik dan vitamin, Kelompok 5 dengan kombinasi antibiotik dan antihistamin, Kelompok 6 dengan kombinasi antihistamin dan vitamin, dan Kelompok 7 dengan kombinasi antipiretik, antibiotik, antihistamin dan vitamin. Didapatkan bahwa pengobatan yang memberikan keberhasilan paling baik tanpa terjadinya kejadian berulang ada pada Kelompok 1 dengan kombinasi antara antibiotik, antipiretik, dan vitamin. Lidocaine merupakan analgesik berfungsi untuk mengurangi rasa sakit dan dypirone berfungsi untuk mengurangi efek inflamasi, lalu adapula Oksitetrasiklin yang berperan sebagai antibiotik yang bekerja secara bakteriostatik, sedangkan

Vitamin B dan multivitamin akan memberikan energi dan mengurangi gejala lemah. Pada penelitian Widhyari, dkk, (2015), dilakukan penanganan defisensi mineral $\mathrm{Zn}$ dengan memberikan larutan mineral $\mathrm{Zn}$ konsentrat sebanyak $60 \mathrm{ppm}$ yang dicampurkan dengan pakan sapi. Terjadinya defisiensi mineral $\mathrm{Zn}$ pada sapi dapat menyebabkan terhambatnya pematangan proses spermatogenesis \& oogenesis sehingga kualitas sperma yang dihasilkan sapi jantan akan buruk. Hasil penelitian ini didapatkan bahwa pengobatan ini mampu membuat motilitas serta konsentrasi dari sperma sapi jantan meningkat tanpa mempengaruhi volume dari semen, warna sperma, konsistensi, daya hidup, dan $\mathrm{pH}$ dari sperma. 
Penelitian yang dilakukan Arthington, et. al., (2014) pula memformulasikan pengobatan untuk sapi yang mengalami defisensi mineral dengan cara pemberian injeksi subkutan sebanyak $1 \mathrm{ml}$ dengan komposisi obat berupa mineral $\mathrm{Cu}$, Se, dan $\mathrm{Zn}$ terbukti meningkatkan kadar mineral tersebut dalam tubuh serta meningkatkan kadar APP plasma.

\section{Kesimpulan}

Mineral merupakan senyawa penting dalam tubuh yang dapat mempengaruhi fungsi fisiologi dari tubuh. Terjadinya defisiensi mineral dapat menyebabkan beberapa gangguan fungsi tubuh dan organ, penyakit bahkan kematian. Beberapa penyakit atau gangguan yang paling sering muncul akibat defesiensi mineral diantaranya adalah Anoreksia atau kehilangan nafsu makan hingga terjadi penuruan berat badan secara signifikan, gangguan sistem reproduksi, terjadi retensi plasenta, gangguan fungsi syaraf dan otot. Telah ditemukan beberapa cara pengobatan untuk penyakit defisiensi mineral pada sapi dengan cara oral maupun injeksi seperti intramuskular atau subkutan. Pada masing-masing sediaan telah terbukti mampu meningkatkan kadar mineral yang mengalami defisiensi.

\section{Daftar Pustaka}

Arthington J. D., P. Moriel, P. G. M. A. Martins, G. C. Lamb, dan L. J. Havenga, 2014. Effects of Trace Mineral Injections on Measures of Performance and Trace Mineral Status of Pre- and Postweaned Beef Calves. Journal of Animal Science, Vol. 92(6) : 2630-2640. Anderson, D. E. dan Rings M. 2009. Current Veterinary Therapy dalam Food Animal Practice St. Louis. MO : Saunders Elsevier.

Arifin Zainal, 2007. Pentingnya Mineral Tembaga $(\mathrm{Cu})$ Dalam Tubuh Hewan Dalam Hubungannya Dengan Penyakit. Wartazoa Vol. 17 No. 02 : 93-99.

Arifin Zainal. 2008. Beberapa Unsur Mineral Esensial Mikro Dalam Sistem Biologi dan Metode Analisisnya. J.Litbang Pertanian, Vol. 27(3) : 99-105.

Cahyadi Putu Putra, Ni Ketut Suwiti, Ida Bagus Komang Ardana. 2016. Suplementasi Mineral Pada Pakan Sapi Bali Terhadap Diferensial Leukosit Di Empat Tipe Lahan. Buletin Veteriner Udayan Vol. 8 No. 1 : 8-16.

Darmono. 2007. Penyakit Defisiensi Mineral Pada Ternak Ruminansia dan Upaya Pencegahannya. J. Litbang Pertanian, Vol. 26 (3) :

104-108.

Duchateau, L. and Janssens, G. P. J., 2013. Mineral Deficiency Status of Ranging Zebu (Bos Indicus) Cattle Around The Gilgel Gibe Catchment, Ethiopia. Trop Anim Health Prod Vol. 45:1139-1147.

Devi G, Sharman MC, Dimri U, Shekhar P, dan Deepa PM. 2014. Micromineral Status Of Soil, Fodders and Cattle From Idukki and Ernakulam Districts of Kerala State, India and Their Interrelation. Int. Journal of Advanced Research, Vol. 2(7): 11-15. 
Dian Ni Komang Sri Sujani, Wayan Piraksa, dan Ni Ketut Suwiti, 2014. Profil Mineral Magnesium dan Tembaga Serum Darah Sapi Bali yang Dipelihara di Lahan Tegalan. Buletin Veteriner Udayana Vol. 6 No. 2 : 119-123.

Dwipartha Putu Satya, I Nyoman Suarsana, dan Ni Ketut Suwiti. 2014. Profil Mineral Kalium (K) Dan Kobalt (Co) pada Serum Sapi Bali yang Dipelihara Di Lahan Perkebunan. Buletin Veteriner Udayana Vol. 6 No. 2 : 125-128.

Elhashmi Y. Hilal, Mohamed A. E. Elkhairey, dan Ayman O. A. Osman, 2016. The Role of Zinc, Manganse and Copper in Rumen Metabolism and Immune Function. Open Journal of Animal Sciences Vol. 6 : 304-324.

Hefnawy, A.E.G. dan Tórtora-Pérez, J.L. 2010. The importance of selenium and the effects of its deficiency in animal health. Small Rumin. Res. Vol $89: 185-192$.

Herdt, T.H. and Hoff, B., 2011. The Use of Blood Analysis to Evaluate Trace Mineral Status in Ruminant Livestock. Food Animal Practice Vol. 27 : 255-283.

Kurnia Frans, M. Suhardiman, L. Stephani, dan T. Purwadaria, 2012. Peranan NanoMineral Sebagai Bahan Imbuhan Pakan Untuk Meningkatkan Produktivitas dan Kualitas Produk Ternak. Wartazoa Vol. 22 No. 4 : 187-192.

Lawton, S., 2013. Mineral Supplements for Beef Cattle. Diakses online di http://www.caes.uga.edu/publicatio ns/pubDetail.cfm?pk_ID=7650 [Diakses pada 20 Juni 2019].

Lean, I. J., De Garis, P. J., McNeil, D. M. and Block, E., 2006. Hypocalcaemia in Dairy Cows: Metaanalysis and Dietary Cation Anion Difference Theory Revisited.

J. Dairy Sci., Vol 89: 669-684.

Liyanan, Elis Septianingrum dan Bram Kusbiantoro, 2015. Kandungan Unsur Mineral Seng (Zn), Bioavailabilitas dan Biofortifikasinya Dalam Beras. Jurnal Sungkai Vol. 3 No. $2: 65-73$.

Mehdi, Y.; Hornick, J.L.; Istasse, L.; dan Dufrasne, I., 2013. Selenium In The Environment, Metabolism and Involvement in Body Functions. Molecules Vol. 18 : 32923311.

Nururrozi Alfarisa, Mulya Fitranda, Soedarmanto Indarjulianto dan Yanuartono. 2016. Bovine Ephemeral Fever pada ternak sapi potong di Kabupaten Gunungkidul, Yogyakarta. Jurnal IImu-IImu Peternakan Vol. 27 (1): 101 - 106.

Ogren, G., 2013. Phosphorus to Horses and Cows. Uppsala : Department of Animal Nutrition and Management Swedish University of Agricultural Science.

Sattler, N. dan Fecteau, G., 2014. Hypokalemia Syndrome in Cattle. Veterinary Clinics of North America: Food Animal Practice Vol. 30(2): 351-357. 
Soetan KO, Olaiya CO, dan Oyewole OE. 2010. The importance of mineral elements for humans, domestic animals and plans. African J. of Food Sci, Vol. 4(5) : 200 -222.

Timothy AR, John DL, Brian IM, Jesse PG, Ronald LH. 2011. Prevalence of Subclinical Hypocalcemia in Dairy Herds. The Veterinary Journal Vol. 188 : 122 - 124.

Widhyari SD., 2012. Peran dan Dampak Defisiensi Zinc (Zn) Terhadap Sistem Tanggap Kebal. Wartazoa, Vol. 22(3) : 141-148.

Yasothai, R. 2014. Importance Of Minerals On Reproduction In Dairy Cattle. International Journal of Science, Environment and Technology Vol. 3 No 6: 2051 2057.

Yanuartono, Alfarisa Nururrozi, Soedarmanto, Indarjulianto, dan Hary Purnamaningsih. 2016. Peran Makromineral pada Reproduksi Ruminansia. Jurnal Sain Veteriner, Vol 34(2) : 155-165.

Żarczyńska K., A. Snarska, L. Rytel, P. Sobiech, 2018. Effect of A Single Dose Parenteral Selenium Supplement Administered to Pregnant Dairy Cows on Selenium and Iron Concentrations and Immune Status of Calves. Polish Journal of Veterinary Sciences Vol. 21 No. 2 : 401-403. 